\title{
THE SOCIAL DIMENSION OF CIVIL LIABILITY. FUNDAMENTAL BENCHMARKS
}

\author{
M. P. Costache
}

\section{Mirela Paula Costache}

Faculty of Law, Private Law Department

"Danubius" University of Galati, Romania

*Correspondence: Mirela Paula Costache, 3 Galati Blvd, 800654 Galati, Romania

E-mail: mirelacostache@univ-danubius.ro

\begin{abstract}
This study examines the concept of liability, as seen from a social perspective, whether we relate to civil liability as an essential form of manifestation of essential legal liability. The civil liability is not a creation of the law, but it finds the values that it defends in the social normativity, as the law emerged along with the society.
\end{abstract}

Keywords: social liability, civil liability, social normativity, prejudice.

\section{Introduction}

It is undeniable that the liability exceeds the law domain, it belongs and it claims intrinsically the social sphere, by its very nature, thus referring to the social liability. The scientific concerns to theorize and to deepen the concept of social liability are recorded at the level of various social sciences, which places the eternal "homo sapiens" in the center of theories. Whether we present from the perspective of the philosopher, sociologist researcher or politician, or we approach the issue from the ethical and moral, legal or economic point of view, the concept of social liability is circumscribed to human existence. And because the law appeared along with the society, the first attempts of human cohabitation have generated also the first manifestations loaded with legal substance. One of the forms of legal liability, the civil one, claims intrinsically the social origin, contributing by the nature of its principles to the protection of the subjective rights of the person.

\section{The Social Liability and its Forms of Manifestation}

The man, a social being, participates within the society with his whole mechanism of experiences and concerns, he relates permanently in a common language with the rest of his peers, in an open and reversible mechanism in which, the society, in turn, becomes "an educator of human reason." Therefore, the human relations are established and implemented in accordance with certain rules (whatever their nature, seen as existential landmarks), established or predetermined ${ }^{2}$ by the integrating collectivity, thus by the society.

The conduct of an individual, as Nicolae Popa mentioned, can be described as a "pragmatic sequence of attitudes, active or passive, as executions of certain operations or programs and as expectations or abstentions in other circumstances..." . We conclude that, depending on the diversity of human activity, it widens also the scope of behavior rules

\footnotetext{
${ }^{1}$ Alain Supiot, Homo Juridicus. Eseu despre funcția antropologică a dreptului. Translated by Cătălina Teodora Burgă and Dorin Raț, "Rosetti Educațional” Publishing House, Bucharest, 2005, p. 11.

2 Ibidem. The same author identifies in his work the sources of law by acceding to the "homo juridicus", namely: the law and the contract, justified by what we are obliged to respect and to what we oblige ourselves through a free agreement of will. Legally, these sources transpose within the principles "pacta sunt servanda" that is the principle of contractual freedom.

${ }_{3}^{3}$ Nicolae Popa, Dimensiuni ale conduitei umane. Perspectivă praxiologică. In „Conduită, norme şi valori”, Bucharest, "Politică" Publishing House, 1986, p. 19.
} 
problematic, rules that differ, depending on the nature and their content: moral, ethical, religious, legal, economic, political rules, etc. ${ }^{4}$ The scope of social liability covers therefore a wide range of manifestation such as: moral, ethical, legal, political, economic, religious liability, etc. With a wide range of manifestation, the social liability diversifies in relation to the nature and the content of the norms which governs it and obviously they can coexist. For example, different forms of social and moral liability can sometimes be merged into the legal one or vice versa. While the legal norm relates to the social individual, a member of a group, which can compel behavioral reactions, the norm of moral liability comes from within him, targeting the self-conscious individual.

Whether we are refer to humans as physical, biological, spiritual entity (all such rules are viewed cumulatively, they do not exclude themselves) or as legal entity, the man identifies in this global social horizon with a projection of a permanent mechanism of interaction at all levels, aiming at the satisfaction of some interests, within the social normativity ${ }^{6}$ limits. This normative dimension requires a behavioral model to meet certain social values.

Our intention is not to exhaustively analyze the ratio problem of social normativity in relation to the individual and his behavior, which mainly is required to the philosophical, psychological, sociological domain ${ }^{7}$. However, the subject submitted to the research requires a substantive approach to the problem. So why do we need these limits of the social normativism?

Human behavior, in full compliance with the principle of freedom, can overcome by certain manifestation what the social norms have imposed, without finding a correspondent within these norms that balance the social order. Gh. Boboş states that, in case of violation or breach thereof, it shall trigger "certain social reactions" for rejecting the behavior of the person who has deflected from the norm. And thus, in the case of deviation or noncompliance, it intervenes as a remedy to social liability. ${ }^{8}$ We can say therefore that the liability (social) becomes a compulsory reference to social order.

Defining and assessing the types of actions and behaviors in the society, the law and the legal normativity have mandatory features, establishing what must do the individuals engaged in specific social actions, what they can do or what it is prohibited. Any norm involves both its acceptance and compliance by the people.

The social norms also contain rules for the behavior of individuals, describing and detailing the ways in which the values should be embodied in legitimate and socially acceptable behaviors. The option of a person to choose to conduct an activity, assuming as an effect a particular conduct, involving the debut of making up his social responsibility. But the

\footnotetext{
${ }^{4}$ Popescu, Adam, Teoria dreptului, Bucharest, "Editura Fundației România de Mâine” Publishing House, 1999, p. 173.

${ }_{5}^{5}$ Mircea Djuvara, Teoria generală a dreptului. Drept raţional, izvoare şi drept pozitiv, All Publishing House, 1995, pp. 135-137. The author identifies only the human person as participant within the social relations: "it can only conceive a legal relationship among people".

${ }^{6}$ The specialized literature specific to the general theory of law domain ruled unanimously on the subordination of social activity normativity, i.e. a set of norms, principles, social rules. For a general overview of the issues, see Gheorghe Boboş, Teoria generală a statului şi dreptului, "Editura Didactică şi Pedagogică" Publishing House, Bucharest, 1983, pp. 260-262; Nicolae Popa, Mihail-Constantinescu Eremia, Simona Cristea, Teoria generală a dreptului, Ediția a 2-a, All Beck Publishing House, Bucharest, 2005, pp. 287-288; Andrei Sida, Teoria generală a dreptului, Vasile Goldiş University Press, Arad, 2004, pp. 190-191; Adam Popescu, op. cit., pp. 173-174.

7 As samples of normative thinking, we may give some Socratic assertions as: "we must not do harm", and efforts to answer questions such as: "what is right, what is moral, what is required to do / not do?"

8 "Social liability involves the social sanction of the attitude chosen by the individual in cases of discrepancy between its behavior and the stated social norms." See George Boboş, op. cit., p. 261.
} 
human activity presupposes a variety of dimensions, of manifestations that are not in their integrity, subsumed to the regulations of the social norms to which we referred earlier.

By an extension on this interpretative approach, the social normativism leaves sometimes at hand to individuals to procure their own conduct in the establishment of certain social relations ${ }^{9}$, in which case there is no overlapping of the imperative will of the society of the individual. In this situation, the individual has at his disposal, along with those of legitimate behaviors, also a freedom space of the choice of their behavior. ${ }^{10}$ But in this respect, their manifestation dictated by the principle of freedom is subordinated to social consciousness, so that the freedom and the liability become two complementary and inseparable concepts. The conclusion: man is not conscious and free unless he is responsible ${ }^{11}$; and vice-versa.

In many research papers in the field of law theory, the authors claim the same point of view: the liability is pointless if the individual does not have free will, the freedom of choosing from many variants of behavior. Freedom of choice is a real prerequisite for social liability, a liability which requires a conscious attitude, reflected by a private or public behavior that reflects the awareness of this attitude. ${ }^{12}$

But what would happen if freedom would not be controlled by the effect of the social norms? Some voices argue the occurrence of the social disasters, even anarchy, while other more pragmatic researchers analyzed the sources of guilt and penalty, when a pre-existent rule is violated, referring to all types of sanctions: moral, legal and civic. In contrast, a normal social attitude of the individual reinforces the belief in the available individual freedom. In this case, the role play between liability-liberty gives birth to an ethics of the human behavior.

We may retain the definition of social liability as being that special social relationship established between the individual and the society, the act or the conduct of the individual being surrounded by the society in the limits of some rights, freedoms, duties, prerogatives established by the rules, principles or values of that society and whose failure attracts one or other forms of social sanctions. ${ }^{13}$

\section{The Specifics of Civil Liability as Aspect of Social Liability}

The social liability in relation to other forms of liability forms translates through the relationship between gender and species. One of these derived forms is represented by the legal liability, "the cornerstone" 14 of all social liability.

The man was forced to think and act legally, a conduct symbolically represented in Latin ubi societas, ibi jus, creating the corpora of the legal norms ${ }^{15}$ by which he organized his

\footnotetext{
${ }^{9}$ We refer to the legal relationships of private law governed by the norms, especially in the contractual domain.

${ }^{10}$ Andrei Sida, op. cit., p. 233.

${ }^{11}$ Yvonne Lambert-Faivre, L' Ethique de la responsabilite, in RTDC no. 1/1998, p. 2 apud Constantin Teleagă, Armonizarea legislativă cu dreptul comunitar în domeniul dreptului civil. Cazul răspunderii pentru produse defectuoase, Rosetti Publishing House, Bucharest, 2004, p. 22.

${ }^{12}$ The same opinion is shared by the author Nicolae Popa, who believes that the social action is the direct liability framework and that freedom is a fundamental condition of liability. "The social liability occurs while the individual deliberately chooses a variant of social behavior, it implies autonomy regarding the choice of its social action”. In this regard, see Nicolae Popa op. cit., p. 198. Also see Dmitrii Baltaga, Teoria răspunderii juridice: aspecte doctrinare, metodologice şi practice. Teză de doctor habilitat în drept, Chişinău, 2008, p. 32.

${ }_{13}$ Andrei Sida, op. cit., p. 234.

${ }^{14}$ Liviu Pop, Drept civil român. Teoria generală a obligațiilor, Lumina Lex Publishing House, Bucharest, 1998, p. 163. The metaphorical formulation of the author develops on a legal level an overwhelming reality: the social activity, at the size of the one which develops nowadays, requires optimal and legal coordination harmonization of rules of law with the individual's behavioral intentions, accompanied by the related restraints.

${ }^{15}$ The legal norm is defined as a rule of general, impersonal and mandatory, repeatable conduct, issued by the state power, accomplished, if necessary, by the coercive power of the state. See, Gheorghe Mihai, Fundamentele dreptului, I-II, All Beck Publishing House, Bucharest, 2003, pp. 290-291.
} 
own needs. The social order is maintained by corroborating these principles, norms, rules ${ }^{16}$, resulting in a complex legal normativity, the rule of law. In this context, it is natural the question what is specific to legal liability?

In one referential approach to the meaning of the liability term in the Dicționarul explicativ al limbii române/Explanatory Dictionary of the Romanian Language, the notion of liability ${ }^{17}$ is defined as "the fact of answering; the obligation to answer to the performance of an action, task, etc., liability, and in the legal sense - the resulting consequence from the failure of a legal obligation. To answer is to be accountable, to be responsible, to vouch for someone." 18

The French dictionary Le Robert indicates the polysemy of which enjoys the term submitted to the discussion: "1. The obligation of ministers to resign when the legal power grants the lack of confidence vote; 2 . The obligation to repair the damage caused by his own fault or (in some cases) the one provided by law, 3. Intellectual or moral obligation to repair the prejudice by the execution of the duty, obligation, contract". ${ }^{19}$

Since the rules of judicial conduct have different natures, it also emerges the form of civil liability, which is represented by a fundamental category, a complex institution of civil law. In this sense, from the economy of past civil legislation, but also from the current one, which do not explicitly define this institution, we may specify that the civil liability represents a form of legal liability, which consists of a compulsory legal relation, according to which a person has a duty to repair the unjust prejudice suffered by another person. ${ }^{20}$

In addition to the civil liability qualification as a form of legal liability, we should mention that the civil liability also represents a legal institution that includes all the rules of law governing the obligation of persons to repair the damages caused by the breach of contractual provisions or by the extra-contractual facts.

Regarding the importance of civil liability as a form of social liability we retain the practical utility of civil liability which, having as aim the repairing of any prejudice caused to a person, there are grafted sometimes other forms of liability which accompanies or complements them in order to restore the order of law. Regardless of its nature, conflicting or contractual, the civil liability, through its functions, principles and conditions, aims at the restoration of the rule of law. This assertion is true even if the civil action, which has as finality the repairing of the prejudice, it is not started ex-officio, as in the case of criminal liability, but at the demand of the complainant. This aspect claimed to private law does not outline the idea that in the event of such prejudice (of civil nature), the society would not be interested in repairing it. The degree of guilt of the offender is submitted also to a social odium. The victim reports this injustice, addressing to those in the position to investigate. The arguments are supported also by the fact that the victim is not the one who sanctions the illicit act of the offender, but the society still, by the state bodies entrusted with this role. Also, the coercive force is still the prerogative of those state entities. ${ }^{21}$ In this case we are analyzing the classical concept of a repairing liability.

\footnotetext{
${ }^{16}$ All these current normative rules in a state unit form the positive law.

${ }^{17}$ Comes from the Latin word respondere.

18 *** Dicționarul Explicativ al Limbii Române, ediţie revăzută şi adăugită, "Univers Enciclopedic Gold" Publishing House, Bucharest, 2009, p. 918.

${ }^{19}$ Robert, P., Dictionnaire alphabétique française, Paris, 1980, p. 880. In Dicționarul explicativ Oxford is stated: "1. Being responsible means doing something without being forced or without advising someone, 2. The fact for which a person is liable is called obligation".

${ }^{20}$ Sache Neculaescu, Reflecții privind fundamentul răspunderii civile delictuale In Dreptul nr. 11/2006, p. 41.

${ }^{21}$ For a comprehensive view of this issue, see Eugenia-Carmen Verdeş, Răspunderea juridică. Relația dintre răspunderea civilă delictuală şi răspunderea penală, "Universul Juridic” Publishing House, Bucharest, 2011, pp. 75-78.
} 
The evolution of society characterized by resizing the activities and relationships between individuals highlighted lately the superiority of the preventive function of the liability $^{22}$, comparing to the classical repairing function. The precautionary legal principle derives and it is based on social considerations and attitudes: it has as objective the prevention, reduction, or even avoiding potential risks to human life and health, and also for the environment. ${ }^{23}$ Hence the contribution of civil legal liability in the prevention and discipline of contractual and extra-contractual civil legal relations, that is it permanently arises in human consciousness the idea to act with care, not disturbing or damaging the interests of others.

\section{Conclusions}

According to the above we deduce that every individual has a "debt" to the society by which it affirms as legal personality, increasingly dynamic by the chosen social conduct. It should be mentioned that it is excluded for each individual to meet its own system of rules that could be applied individually. Thus, we consider that a certain content prescribed by a rule applies to all individuals formed in defined communities, retaining the general feature ${ }^{24}$ and the repeatability of social normative dimension. The civil liability through its functions and its finality accompanies and supports the development of social life, contributing to the protection of subjective rights of individuals.

\section{Bibliography}

Liviu Pop, Tratat elementar de drept civil. Obligațiile, "Universul Juridic" Publishing House, Bucharest, 2012.

Eugenia-Carmen Verdeş, Răspunderea juridică. Relația dintre răspunderea civilă delictuală şi răspunderea penală, "Universul Juridic" Publishing House, Bucharest, 2011.

*** Dicționarul Explicativ al Limbii Române, ediție revăzută şi adăugită, "Univers Enciclopedic Gold” Publishing House, Bucharest, 2009.

Lacrima Rodica Boilă, Răspunderea civilă delictuală obiectivă, C.H. Beck Publishing House, Bucharest, 2008.

Dmitrii Baltaga, Teoria răspunderii juridice: aspecte doctrinare, metodologice şi practice. Teză de doctor habilitat în drept, Chişinău, 2008.

Alain Supiot, Homo Juridicus. Eseu despre funcția antropologică a dreptului. Translated by Cătălina Teodora Burgă and Dorin Raț, "Rosetti Educațional" Publishing House, Bucharest, 2005.

Nicolae Popa, Mihail-Constantinescu Eremia, Simona Cristea, Teoria generală a dreptului, Ediția a 2-a, All Beck Publishing House, Bucharest, 2005.

Andrei Sida, Teoria generală a dreptului, Vasile Goldiş University Press, Arad, 2004.

Yvonne Lambert-Faivre, L' Ethique de la responsabilite, in RTDC nr. 1/1998, p. 2 apud Constantin Teleagă, Armonizarea legislativă cu dreptul comunitar în domeniul dreptului civil. Cazul răspunderii pentru produse defectuoase, Rosetti Publishing House, Bucharest, 2004. 2003.

Gheorghe Mihai, Fundamentele dreptului, I-II, All Beck Publishing House, Bucharest,

\footnotetext{
${ }^{22}$ This theory was developed and supported in our doctrine by several authors. We note the scientific contribution on the issue presented by the author Lacrima Rodica Boilă, Răspunderea civilă delictuală obiectivă, C.H. Beck Publishing House, Bucharest, 2008, pp. 73-79.

${ }^{23}$ Liviu Pop, Tratat elementar de drept civil. Obligațiile, "Universul Juridic" Publishing House, Bucharest, 2012, p. 402.

${ }^{24}$ Relating to the individual's personality, the rule of law, by the established conduct, it is characterized by generality and repeatability.
} 
Popescu, Adam, Teoria dreptului, Bucharest, "Fundaţia România de Mâine" Publishing House, 1999.

Liviu Pop, Drept civil român. Teoria generală a obligațiilor, Lumina Lex Publishing House, Bucharest, 1998.

Mircea Djuvara, Teoria generală a dreptului. Drept rațional, izvoare şi drept pozitiv, All Publishing House, 1995.

Nicolae Popa, Dimensiuni ale conduitei umane. Perspectivă praxiologică. In „Conduită, norme şi valori”, Bucharest, "Politică” Publishing House, 1986.

Gheorghe Boboş, Teoria generală a statului şi dreptului, "Editura Didactică şi Pedagogică" Publishing House, Bucharest, 1983.

*** Oxford Advanced Garner Dictionary of English, 1997.

Robert, P., Dictionnaire alphabétique française, Paris, 1980. 